\title{
Expression of Luteinizing Hormone (LH) Subunit Genes in Mouse Testis
}

\author{
Hee Soo Kim and ‘'Sung-Ho Lee \\ Department of Life Science, Sangmyung University, Seoul 03016, Korea
}

\begin{abstract}
Gonadotropins are heterodimers consisting an alpha chain $(\mathrm{Cg} \alpha)$ and a beta chain. Interestingly, presence of complicated LH- $\beta$ transcripts in rat testis was accidently found; testicular LH- $\beta$ transcripts were confined in seminiferous tubules to spermatids, and the translated products were localized in the elongated spermatids. We hypothesized that mouse testis has potential to produce the tissue specific LH- $\beta$ with similar structure to the rat testicular forms. To verify our hypothesis, we examined the adult mouse (ICR) testis using RT-PCR and immunohistochemistry. The PCR revealed the presence of the identical products in the reactions for three LH subunit types. The expected product sizes for mouse Cg $\alpha$ and LH- $\beta$ known as pituitary type were 224 bp and 503 bp, respectively. The testicular type LH- $\beta$ products were produced by a primer set based on the rat sequences, with unexpected size of $800 \mathrm{bp}$. Sequencing revealed that the proximal and distal parts (2-82 and 661- $773 \mathrm{bp}$, respectively) were homologous to rat testicular LH- $\beta$ cDNA, and middle part (83-660 bp) was a unique mouse-specific region. Both $\mathrm{Cg} \alpha$ and LH- $\beta$ positive signals were in the round and elongated spermatids and mature sperms, and the LH- $\beta$ signals were more intense. In conclusion, our study demonstrated that the presence and localization of the LH subunits in mouse testis. Further studies will be needed to understand the precise structure and function of mouse testicular LH.
\end{abstract}

Key words : Mouse, Testis, Tissue-specific, LH- $\beta$, Spermatid

\section{INTRODUCTION}

Gonadotropins are glycoprotein hormones having a stimulating effect on the gonads. Among them, LH and FSH are secreted by the anterior pituitary gland of all vertebrates and some invertebrates; chorionic gonadotropins(CG) are uniquely secreted by placenta of primate and equine species (Pierce \& Parsons, 1981; Choi \& Smitz, 2014). Gonadotropin and thyroid-stimulating hormone (TSH) are heterodimers consisting of two peptide chains, an alpha $(\mathrm{Cg} \alpha)$ chain and a beta ( $\beta$ ) chain; the $\alpha$ subunits of these four glycoprotein hormones are identical; however, their $\beta$ chains are unique and confer biological specificity. (Fan \& Hendrickson, 2005).

The cDNAs of the gonadotropin subunits, which are encoded by a single gene, have been cloned from the pituitaries of human, mouse, and rat (Fiddes \& Goodman, 1981; Chin et al., 1981; Chin et al., 1983; Godine et al., 1982; Talmadge et al., 1983; Gharib et al., 1989; Kumar \& Matzuk, 1995). Interestingly, presence of more complicated transcripts of LH- $\beta$ subunit gene in rat testis was accidently found when the testis was used as negative control (Zhang et al., 1995a). The authors also demonstrated that expression of testicular LH- $\beta$ subunit was confined in seminiferous

\footnotetext{
Manuscript received September 21, 2017, Received in revised form September 24, 2017, Accepted September 26, 2017

$\dagger$ Corresponding Author : Sung-Ho Lee, Ph.D., Department of Life Science, Sangmyung University, Hongjmoon-2 gil 20, Jongrho-Gu, Seoul 03016, Republic of Korea. Tel: +82-2-2287-5139, Fax: +82-2-2287-0070, E-mail: shlee@smu.ac.kr

This is an Open Access article distributed under the terms of the Creative Commons Attribution Non-Commercial License (http:// creativecommons.org/licenses/by-nc/3.0) which permits unrestricted non-commercial use, distribution, and reproduction in any medium, provided the original work is properly cited.
} 
tubules to spermatids, and the translated products were also localized in the cytoplasm of elongated spermatids (Zhang et al., 1995a).

We hypothesized that mouse testis also has potential to produce the tissue specific LH- $\beta$ subunit with similar structure (i.e. cDNA sequences) to the rat testicular forms. To verify our hypothesis, we examined whether the transcripts for LH subunits and their translated products were existed in the mouse testis using RT-PCR and specific immunohistochemical analyses.

\section{MATERIALS AND METHODS}

\section{Animals and ethics approval}

Adult male ICR mouse (about 5 months old) were obtained from Han-Lim Animal (Gyunggi-do, Korea) and reared in Sangmyung university animal facility under conditions of 12-h light/dark cycle (lights on at 07:00 h) and constant temperature of $22 \pm 1^{\circ} \mathrm{C}$. Mice had free access to normal chow and tap water ad libitum. After allowing 7 days acclimation, mice were sacrificed and the testes and pituitaries were collected for RT-PCRs and immunohistochemistry. All procedures used were approved by the Animal Care and Use Committee (2013-01-03) at Sangmyung University.
2. Total RNA extraction and reverse transcription polymerase chain reaction (RT-PCR)

Total RNAs were isolated from tissue samples using TRIzol Reagent (Thermo Fisher Scientific, USA) according to the manufacturer's protocol. The extracted RNAs were used in RT-PCR reactions carried out with Maxime ${ }^{\mathrm{TM}}$ RT PreMix (iNtRON, Korea) and AccuPower PCR Premix (Bioneer, Korea) according to the manufacturer's instructions. Primer sequences and the specific PCR conditions used in this study were listed in Tables 1 and 2, respectively. The reaction products were analyzed by gel electrophoresis in $1.5 \%$ agarose gel (75 V, $65 \mathrm{~min}$ ) and visualized by ethidium bromide staining. The band intensities were measured using the image analysis system (ImagerIII-1D main software, Bioneer, Korea). The testicular LH- $\beta$ PCR products were used for further analysis of cDNA structure. Sequence analyses were done by a commercial sequencing service company (Macrogen, Korea).

\section{Immunohistochemistry}

The primary antibodies against LH subunits used in this study were obtained from NIDDK-NHPP program as a courtesy of Dr. A. F. Parlow; rabbit polyclonal antibodies against mouse LH- $\beta$ subunit (diluted 1:500) and mouse $\mathrm{Cg} \alpha$ subunit (diluted 1:250). Tissue specimens were fixed in $4 \%$

Table 1. Sequence of the primers used

\begin{tabular}{cccc}
\hline \hline Gene & Accession number & Sequence of the primers & Size of fragment \\
\hline \multirow{2}{*}{ Cg $\alpha$} & NM_009889 & F 5'-CAG GTC CAA GAA GAC AAT GC & 224 bp \\
\cline { 3 - 3 } & NH_ $\beta$ & R 5'-TGA CAC ACA GCG CCA TTG AA & \multirow{2}{*}{503 bp } \\
\cline { 3 - 3 } & F 5'-CCA GTC TGC ATC ACC TTC AC & \\
\hline \multirow{2}{*}{ Testis LH- $\beta$} & XM_006541350.3 & R 5'-AGG GAG GGA GGG ATG ATT AG & \\
\hline
\end{tabular}

F, forward; R, reverse.

The directions of sequences are all 5' to 3'. 
Table 2. Specific conditions of PCRs used.

\begin{tabular}{ccc}
\hline \hline Gene & $\begin{array}{c}\text { Temperature \& time } \\
\text { denature / annealing / extension }\end{array}$ & $\begin{array}{c}\text { Number } \\
\text { of cycle }\end{array}$ \\
\hline Cg $\alpha$ & $94^{\circ} \mathrm{C}, 45 \mathrm{sec} / 63^{\circ} \mathrm{C}$, \\
& $30 \mathrm{sec} / 72^{\circ} \mathrm{C}, 30 \mathrm{sec}$ & 35 \\
\hline LH- $\beta$ & $94^{\circ} \mathrm{C}, 45 \mathrm{sec} / 65^{\circ} \mathrm{C}$, & 35 \\
\hline Testis & $30 \mathrm{sec} / 72^{\circ} \mathrm{C}, 30 \mathrm{sec}$ & 30 \\
LH- $\beta$ & $94^{\circ} \mathrm{C}, 45 \mathrm{sec} / 65^{\circ} \mathrm{C}$, & \\
\hline
\end{tabular}

paraformaldehyde solution, and the fixed tissues were serially dehydrated in graded ethanol and xylene. Specimens were embedded in paraffin block, and the tissues blocks were cut at 6um using microtome (HM350S, MICROM, Germany). After being dewaxed in xylene and hydrated in ethanol to $10 \mathrm{mM}$ sodium phosphate buffered saline (PBS, $\mathrm{pH} 7.2$ ), the sections were subsequently incubated overnight at room temperature with primary antibodies. The sections were incubated with second antibody, goat anti-rabbit IgG conjugated with horseradish peroxidase (Santa Cruz Biotechnology, USA; diluted 1:200), for $2 \mathrm{hr}$. Finally, positive signals were detected by Peroxidase Polymer Anti-Rabbit IgG Kit (Vector Laboratories, USA; diluted 1:50).

\section{RESULTS}

\section{RT-PCR analyses of Cga and LH- $\beta$ subunits in} mice pituitary and testis

To determine whether the mRNAs for both $\operatorname{Cg} \alpha$ subunit and LH- $\beta$ subunit (specifically pituitary or testis type) are present, total RNAs isolated from pituitary (as positive control) and testis of normal adult mice were subjected to RTPCR analyses. The amplifications revealed the presence of the identical products in all three reactions. The expected product sizes for mouse $\mathrm{Cg} \alpha$ and LH- $\beta$ known as pituitary type were $224 \mathrm{bp}$ and $503 \mathrm{bp}$, respectively (Fig. 1A \& 1B). The testicular type of LH- $\beta$ products were produced by a primer set based on the rat sequences, with unexpected size of $800 \mathrm{bp}$ (Fig. 1C). Sequence analysis of this products revealed that the proximal and distal parts (2-82 and 661-773 $\mathrm{bp}$, respectively) were homologous to the rat testicular $\mathrm{LH}$ $\beta$ cDNA, and the relatively long middle part (83-660 bp) was a unique mouse-specific region (Fig. 2A \& 2B).

\section{Immunohistochemical detection of $\mathrm{Cga}$ and LH-} $\beta$ subunits in mouse testis

Immunostaining using anti-Cg $\alpha$ polyclonal antibody was performed on the testis tissue sections from normal adult

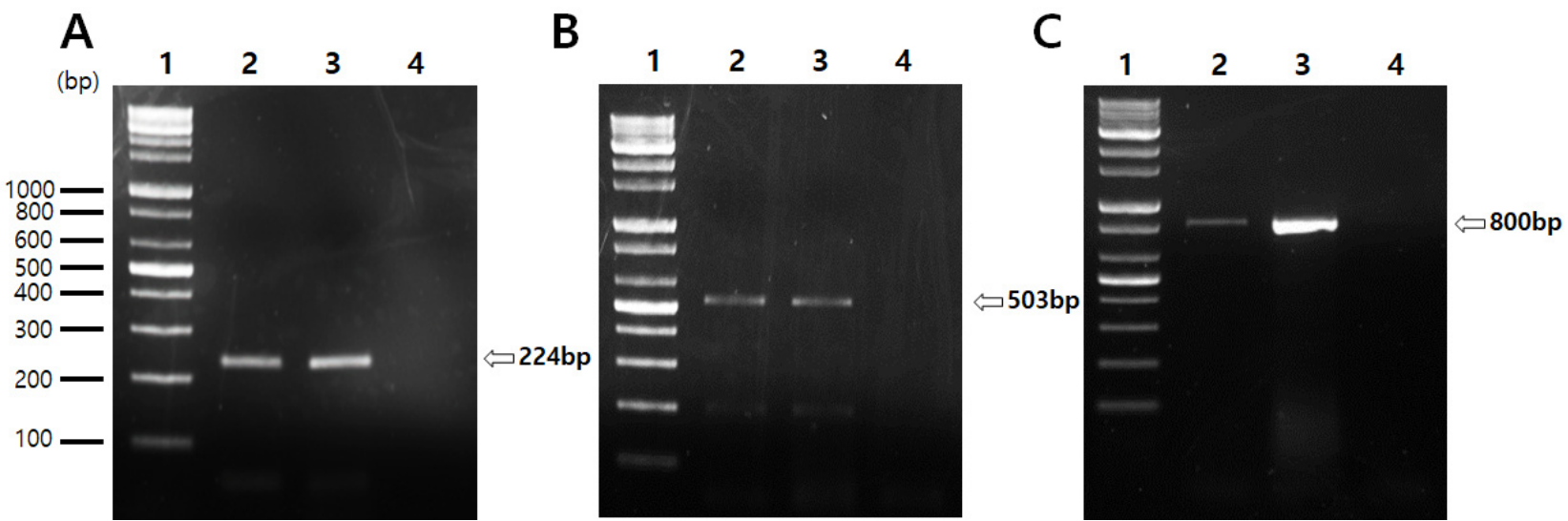

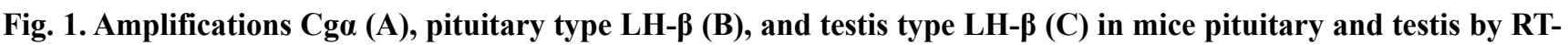
PCRs. The specific primer sequences and reaction conditions were described in Table 1 and 2. The PCR products were resolved on 1.5\% agarose gel containing EtBr Lane 1, DNA size marker; Lane 2, pituitary; Lane 3, testis; Lane 4, PCR without template for negative control. bp, base pairs. 
A

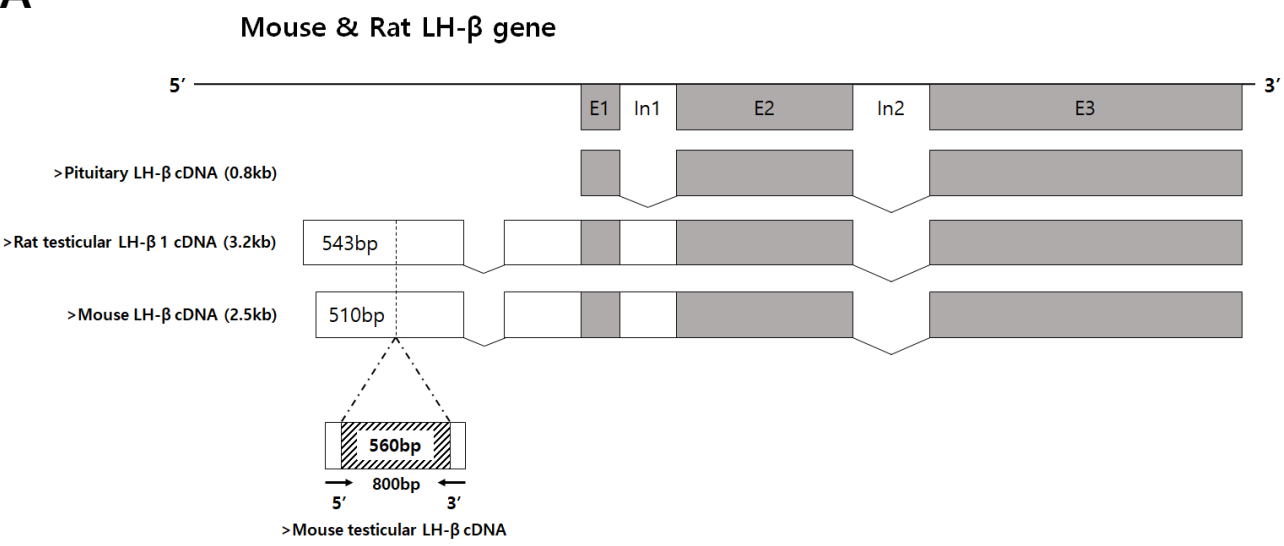

B

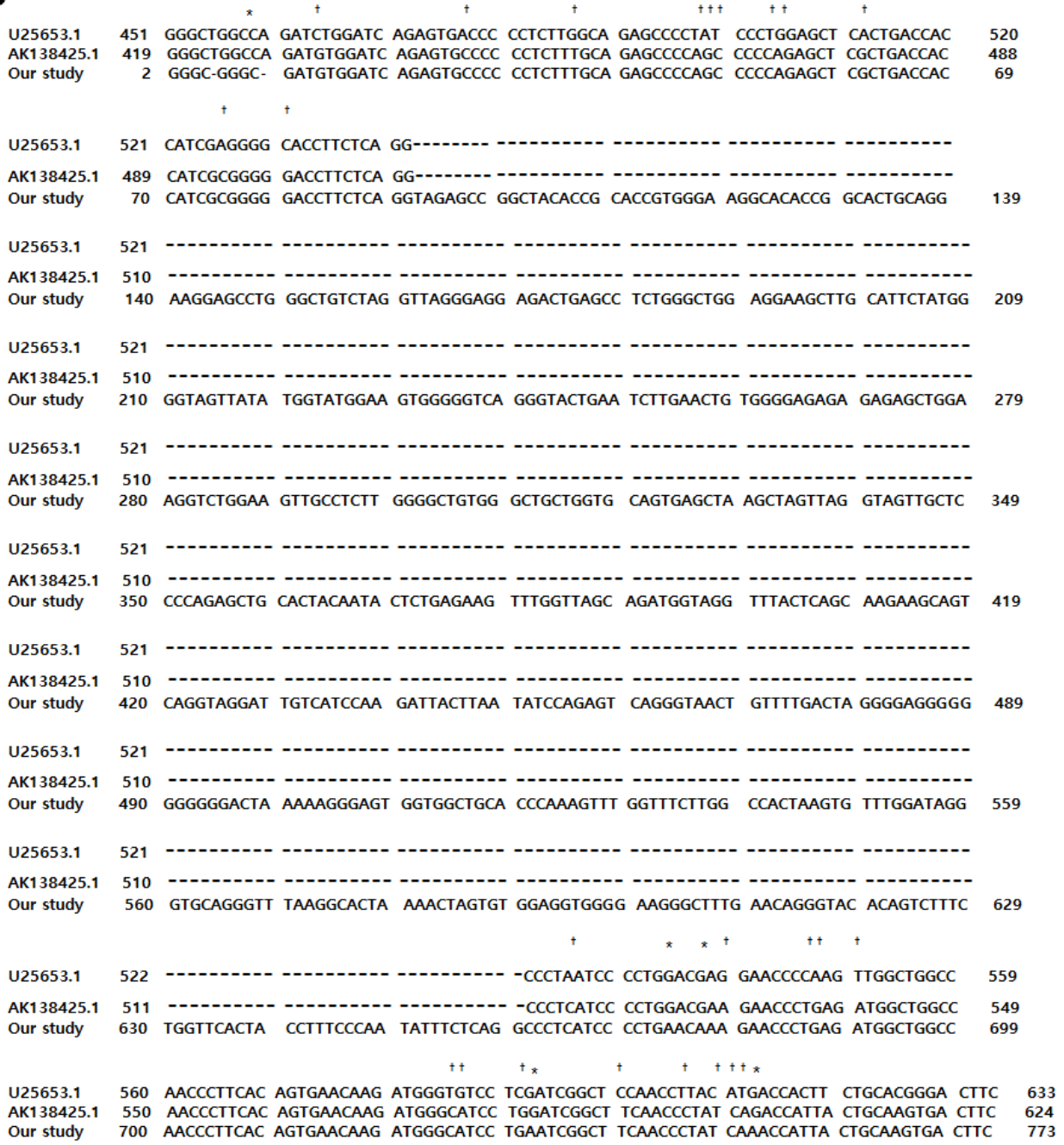

Fig. 2. Sequence analysis of the testis type LH- $\beta$ PCR products (Fig. 1C). (A) Schematic presentation of the pituitary LH- $\beta$ gene and testis type LH- $\beta$ gene in the rat (U25653.1) and mouse (AK138425.1). (B) Sequence of the testis type LH- $\beta$ PCR product in the mouse testis was compared with accession numbers U25653.1 and AK138425.1. Gaps (-) are the same as the sequence of U25653.1 and AK138425.1. bp, base pair; $\dagger$, difference between U25653.1 and our sequence; *, difference between AK138425.1 and our sequence. 


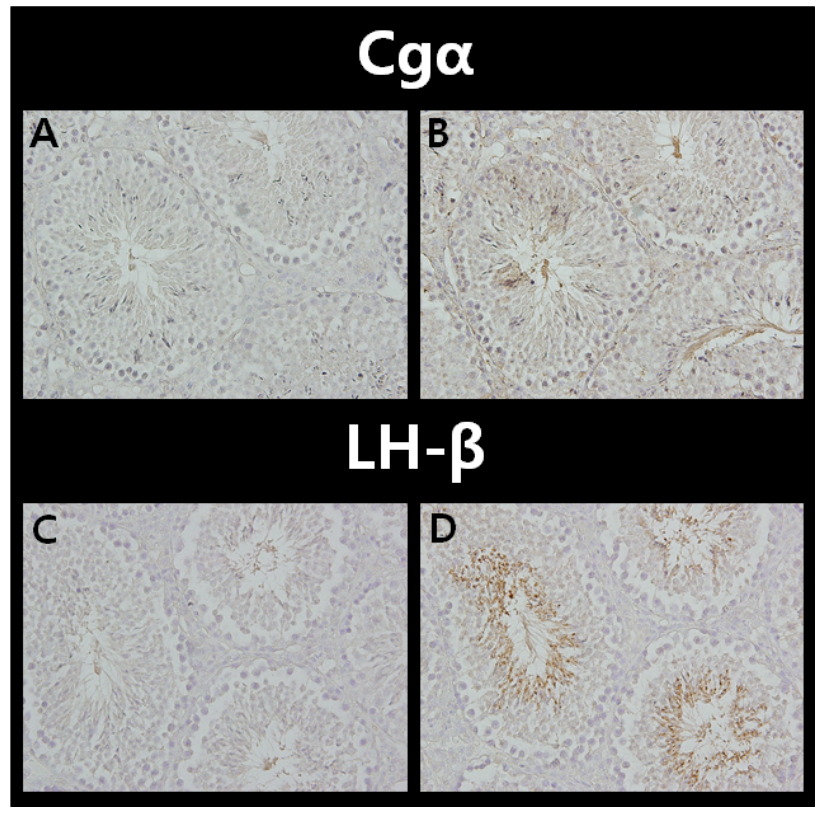

Fig. 3. Immunolocalization of Cga and LH- $\beta$ in the mouse testis. Mouse testes were isolated, fixed in $4 \%$ paraformaldehyde and cut transversely in $6 \mu \mathrm{m}$ thick sections. B and D were shown in the immunohistochemically stained location of Cg $\alpha$ and LH- $\beta$ in the mouse testis, respectively. A and $\mathrm{C}$ were the sections showing negative control without the primary antibody. Magnification, $\times 400$.

mice (Fig. 3B). Cg $\alpha$ positive signals, though weaker than LH- $\beta$ signals, were in the round spermatids, elongated spermatids and mature sperms. The results also showed moderate staining in the cytoplasm of the spermatocytes.

Immunohistochemical analysis of LH- $\beta$ revealed that the more intense positive signals were present in round spermatids, elongated spermatids and mature sperms (Fig. 3D). The negative controls were treated in the same manner as the other samples except PBS was used instead of the primary antibodies against $\mathrm{Cg} \alpha$ or LH- $\beta$ (Fig. 3A \& 3C).

\section{DISCUSSION}

In the present study, we demonstrated for the first time the presence of the transcripts for $\mathrm{Cg} \alpha$ and LH- $\beta$ in mice testis, and the translated products are localized in the round and elongated spermatids and mature sperms. These findings are in good agreement with the results of the previous study on the rat testicular LH expression (Zhang et al., 1995b). Furthermore, we provided evidence on Cg $\alpha$ immunostaining which was omitted in the previous study. The localizations of immunoreactive $\operatorname{Cg} \alpha$ and LH- $\beta$ in mice testis roughly overlapped, and the staining intensities varied; LH$\beta$ signals were stronger than that of $\operatorname{Cg} \alpha$. Particularly, our sequence analysis revealed that the transcripts for mice testicular LH- $\beta$ have unique structure, containing additional part which was not found in the rat testicular transcripts. Whether this unique product is oriented from intron or exon is interesting question. We speculate this could be a part of novel exon, since the product is lacking the typical end dinucletides of most introns (5'-GT and AG-3'). And if genomic DNAs were contaminated in our PCR samples, the LH- $\beta$ PCR for amplification of pituitary type product should also exerted bigger products containing two intron-derived insertions. If the unique product is oriented from intron, the published structure of the rat testicular LH- $\beta$ transcripts (known as TLH $\beta$ 1and 2) in the previous study should be corrected (Zhang et al., 1995b).

Extrapituitary production of LH has been found in many tissues (Harvey et al., 2012). LH is found in the fetal rat brain and persists in the adult rat and human (Hojvat et al., 1982; Bowen et al., 2002), in the pineal gland (Noteborn et al., 1992). The presence of LH receptors in the hippocampus (Lathe, 2001) and cultured neonatal rat brain glial cells (AlHader et al., 1997), suggests that brain LH may stimulate this region and possibly influence synaptic function, and may act as a neuromodulator of reproductive behavior. The local $\mathrm{LH}$ production in the brain as well as its presence in the peripheral tissues is thought to explain the persisted $\mathrm{LH}$ level in the circulation of hypophysectomized rats (Shin et al., 1986; Harvey et al., 2012). Moreover, LH is produced by lymphocytes in blood, and this may act as a cytokine-like determinant of T-cell proliferation (Hotakainen et al., 2000; Sabharwal et al., 1992). And finally, LH is also present in 
the reproductive organs such as gonads (Zhang et al., 1995 a \& b; So et al., 2005) and placenta (Al-Timini \& Fox, 1986), though the its physiological role is unclear. Unlike authentic pituitary LH, serum concentration of the extrapituitary LH is probably too low to induce the endocrine function such as triggering ovulation and stimulating steroidogenesis. Instead, local autocrine or paracrine roles such as fine tuning of target tissue physiology could be suggested. Regarding the mouse testicular LH, one can also postulate its plausible roles by its specific localizations; in the regulation of spermiogenesis and/or capacitation during transport through male and female reproductive tracts.

In conclusion, the present study provides evidence for the presence and localization of the LH subunits in mouse testis. Our ongoing studies on the structures of LH- $\beta$ transcripts and their testis-specific promoter will be useful for precise understanding of local regulation of this gene and preparation of the loss-of-function animal model through conditional knock-out technique.

\section{ACKNOWLEDGEMENT}

The authors are grateful to Dr. A.F. Parlow, UCLA, USA for providing the anti-sera. This research was supported by a 2013 Research Grant from Sangmyung University.

\section{REFERENCES}

Al-Hader AA, Lei ZM, Rao CV (1997) Novel expression of functional luteinizing hormone/chorionic gonadotropin receptors in cultured glial cells from neonatal rat brains. Biol Reprod 56:501-507.

Al-Timimi A, Fox H (1986) Immunohistochemical localization of follicle-stimulating hormone, luteinizing hormone, growth hormone, adrenocorticotrophic hormone and prolactin in the human placenta. Placenta 7:163-172.

Bowen RL, Smith MA, Harris PL, Kubat Z, Martins RN, Castellani RJ, Perry G, Atwood CS (2002) Elevated luteinizing hormone expression colocalizes with neurons vulnerable to Alzheimer's disease pathology. J Neurosci Res 70:514-518.

Chin WW, Godine JE, Klein DR, Chang AS, Tan LK, Habener JF (1983) Nucleotide sequence of the cDNA encoding the precursor of the $\beta$-subunit of rat lutropin. Proc Nat1 Acad Sci USA 80:4649-4653.

Chin WW, Kronenberg HM, Dee PC, Maloof F, Habener JF (1981) Nucleotide sequence of the mRNA encoding the pre-alpha-subunit of mouse thyrotropin. Proc Natl Acad Sci USA 78:5329-5333.

Choi J, Smitz J (2014) Luteinizing hormone and human chorionic gonadotropin: distinguishing unique physiologic roles. Gynecol Endocrinol 30:174-181.

Fan QR, Hendrickson WA (2005) Structural biology of glycoprotein hormones and their receptors. Endocrine 26: 179-188.

Fiddes JC, Goodman HM (1981) The gene encoding the common alpha subunit of the four human glycoprotein hormones. J Mol Appl Genet 1:3-18.

Gharib SD, Roy A, Wierman ME, Chin WW (1989) Isolation and characterization of the gene encoding the betasubunit of rat follicle-stimulating hormone. DNA 8:339349.

Godine JE, Chin WW, Habener JF (1982) Alpha subunit of rat pituitary glycoprotein hormones: primary structure of the precursor determined from the nucleotide sequence of cloned cDNAs. J Biol Chem 257:8368-8371.

Harvey S, Arámburo C, Sanders EJ (2012) Extrapituitary production of anterior pituitary hormones: an overview. Endocrine 41:19-30.

Hojvat S, Emanuele N, Baker G, Connick E, Kirsteins L, Lawrence AM (1982) Growth hormone (GH), thyroidstimulating hormone (TSH), and luteinizing hormone (LH)-like peptides in the rodent brain: non-parallel ontogenetic development with pituitary counterparts. Brain Res 256:427-434.

Hotakainen PK, Serlachius EM, Lintula SI, Alfthan HV, 
Schröder JP, Stenman UE (2000) Expression of luteinising hormone and chorionic gonadotropin beta-subunit messenger-RNA and protein in human peripheral blood leukocytes. Mol Cell Endocrinol 162:79-85.

Kumar TR, Matzuk MM (1995) Cloning of the mouse gonadotropin beta-subunit-encoding genes, II. Structure of the luteinizing hormone beta-subunit-encoding genes. Gene 166:335-336.

Lathe R (2001) Hormones and the hippocampus. J Endocrinol 169:205-231.

Noteborn HP, de Koning J, de Jong FH, Ebels I, Salemink CA (1992) Identification of luteinizing hormone-like proteins in the ovine pineal gland. J Pineal Res 12:118127.

Pierce JG, Parsons TF (1981) Glycoprotein hormones: structure and function. Ann Rev Biochem 50:465-495.

Sabharwal P, Varma S, Malarkey WB (1992) Human thymocytes secrete luteinizing hormone: an autocrine regulator of T-cell proliferation. Biochem Biophys Res Commun 187:1187-1192.

Shin SH, Vincent SG, Maltman C, Obonsawin MC, Stok- reef JC, Reifel CW (1986) Pulsatile release of immunoreactive luteinizing hormone (irLH) in hypophysectomized male rats. Biol Reprod 35:1115-1122.

So WK, Kwok HF, Ge W (2005) Zebrafish gonadotropins and their receptors: II. Cloning and characterization of zebrafish follicle-stimulating hormone and luteinizing hormone subunits: Their spatial-temporal expression patterns and receptor specificity. Biol Reprod 72:13821396.

Talmadge K, Boorstein WR, Fiddes JC (1983) The human genome contains seven genes for the beta-subunit of chorionic gonadotropin but only one gene for the betasubunit of luteinizing hormone. DNA 2:281-289.

Zhang FP, Markkula M, Toppari J, Huhtaniemi I (1995a) Novel expression of luteinizing hormone subunit genes in the rat testis. Endocrinology 136:2904-2912.

Zhang FP, Rannikko A, Huhtaniemi I (1995b) Isolation and characterization of testis-specific cDNAs for luteinizing hormone beta-subunit in the rat. Biochem Biophys Res Commun 210:858-865. 